MedieKultur | Journal of media and communication research | ISSN 1901-9726

Article - Theme section

\title{
Sundhed på tv: \\ fra læge til sundhedsguru
}

\section{Christa Lykke Christensen}

MedieKultur 2013, 54, 104-122

Published by SMID | Society of Media researchers In Denmark | www.smid.dk The online version of this text can be found open access at www.mediekultur.dk

Artiklen beskceftiger sig med den danske public service-kanal, DR's, sundhedsprogrammer i perioden fra 1990'erne til 2012. Undersøgelsen baserer sig på en empirisk, kvalitativ indholdsanalyse af udvalgte programmer om sundhed på DR med henblik på en udredning af det diskursive indhold i forestillinger om sundhed. Programmernes formål, genre, seer-henvendelse og vidensformidlende sigte adresseres. Artiklen er informeret af medialiseringsteori og belyser, hvordan tv-mediet fra at have hentet den sundhedsfaglige ekspertise i institutioner uden for mediet selv, i stigende grad anvender know-how eksperter, tilpasset og iscenesat med henblik på at opfylde de krav, tv-mediet stiller til dramatisk vellykket underholdning. Artiklen belyser, hvordan oplysning om sygdom, behandling og pleje, formidlet af lagevidenskabelig ekspertise og leegfolk, spillede en central rolle i de tidlige oplysningsprogrammer, mens nyere programmer fremstiller sundhed som et ivcerkscetterprojekt, møntet på forbedring og hurtig forandring af individuel adfard og livsstil.

\section{Introduktion}

Sundhed står højt på såvel den politiske dagsorden som i befolkningens bevidsthed, ligesom den udgør et centralt aspekt i moderne livsstil og i det medieforbrug, der knytter sig hertil. Medierne har altid viet sundhedsemner stor opmærksomhed i form af både viden- 
skabelige og populærvidenskabelige tidsskrifter om sundhed (Kline, 2006; Tjønneland 2008), i form af populærkulturens sundhedsstof i magasiner, ugeblade og reklamer (Bonner et al., 1998; Warsh, 2011), i form af den journalistiske beskæftigelse med sundhedsemner i såvel aviser som radio og tv (Eide \& Hernes, 1987; Puijk, 2008; Mølster, 2009; Iversen, 2010), i form af oplysende videnskabsprogrammer på tv (Corner, 1999; Brinch \& Iversen, 2010) og, ikke mindst, i form af sites på internettet, der giver adgang til en nærved uendelig mængde sundhedsinformation (Wright et al., 2008; Lewis, 2008). Medierne er formidlere af alt fra videnskabelige resultater, politiske budskaber og moralske forestillinger til underholdende sensationer, forbrugervejledning og konkrete 'husmor'-råd, hvilket alt sammen dels har et sundhedsoplysende sigte, dels imødekommer et underholdningsbehov hos mediebrugerne. Medierne er derfor ikke blot en neutral arena for formidling af sundhedsstof. De udgør en central aktør i italesættelsen af, hvad der ud fra såvel videnskabelige antagelser som mere populære og folkelige forestillinger betragtes som sundt, og de medvirker til at sætte den sundhedspolitiske dagsorden (Eide \& Hernes, 1987).

Nutidens sundhedseksperter er ligeså optaget af at justere på den mad, vi spiser, og den måde, vi indretter bolig, have og familieliv på, som på vejledning i forhold til krop og sjæl. Sundhed er derfor ikke kun et spørgsmål om, hvorvidt det enkelte menneske er sygt eller ej. Sundhed handler i dag om adfærd og livsstil, om livskvalitet og om mulighederne for at fremme 'det gode liv'. Dette sundhedssyn blev for alvor knæsat med verdenssundhedsorganisationen WHO's definition af sundhed som "a state of complete physical, mental and social well-being and not merely the absence of disease and infirmity" (WHO, 1946). Definitionen erklærer, at enhver principielt kan og bør få en sund tilværelse, at sundhed og sygdom ikke nødvendigvis er hinandens modsætninger og, som Wright et al. påpeger, fremstiller erklæringen sundhed og sygdom som dynamiske processer fremfor som stabile størrelser: "both health and disease are seen as being in a constant state of change" (2007, p. 5). Sundhed fortolkes derfor først og fremmest som sundhedsfremme, hvor begrebets indhold i retning af potentiel forbedring og forandring står i fokus. Det får en utopisk karakter og beskriver snarere en idealtilstand end en eksisterende tilstand (Qvarsell, 1989).

Med øget fokus på livskvalitet som en parameter for sundhed er sundhedsbegrebet generelt konvergeret med opfattelser af, hvad social og kulturel identitet er og bør være (O'Brien, 1995); ikke mindst har det resulteret i en forståelse af sundhed som et individuelt forbedringsprojekt, hvor det enkelte individ bør tage ansvar for sin egen sundhed (Featherstone \& Hepwoth, 1991). Fokus på livsstilsfaktorer er også synligt på den danske sundhedspolitiske arena. Selv om levevilkårs- og folkesundhedsundersøgelser (Danmarks Statistik, 2012; Juel et al., 2006) gentagende peger på, at folks sociale og økonomiske vilkår spiller en afgørende rolle for deres muligheder for 'frit' at vælge bestemte former for livsstil og dermed sundhed, er individuel adfærd og livsstil på det danske sundhedspolitiske område igennem de seneste godt tyve år vedvarende blevet understreget som årsagsforklaringer i forhold til befolkningens sygdoms- og sundhedstilstand (Vallgårda, 2003). Fremstillingen af sundhed som et individuelt ansvar og tilvalg (Regeringen, 1989; Regeringen, 
2002), har politisk givet sig udslag i prioritering af strategier, der "kom (...) til at handle om at få folk til at styre sig selv i en anden retning" (Vallgårda, 2003, p. 141); En tendens, der også har slået igennem i diverse tv-programmer om sundhed, hvilket vi skal vende tilbage til.

Når sundhed ikke blot er et spørgsmål om, hvorvidt det enkelte menneske er sygt eller ej, men drejer sig om god livskvalitet, når sundhed bliver en distinktionsmarkør i forhold til forbedring af adfærd og livsstil, og når sundhed ikke er en tilstand, men en proces, der aktivt skal tilvælges og forbedres, bliver viden om, hvad der kan fremme sundheden, vigtig. Selv om folk benytter sig af deres sociale netværk eller deres læge til at skaffe sig information om sundhedsspørgsmål, spiller medierne en afgørende rolle for forståelsen af, både hvad der i dagens samfund kan henregnes under kategorierne 'livskvalitet' og 'det gode, sunde liv' (Wright et al., 2008; Iversen, 2010) og af hvem, der sidder inde med ekspertisen til at formidle denne viden.

\section{Medialisering af sundhed}

Det teoretiske rammeværk omkring artiklen udgøres af tesen om medialisering af moderne samfund og kultur (Hjarvard, 2004, 2008; Strömbeck, 2008; Schulz, 2004), og det spørgsmål skal besvares, om der på linje med medialisering af fx politik, religion og sprog (Hjarvard, 2008) er tale om tilsvarende medialiseringsprocesser, når vi har med sundhed at gøre.

Som det er tilfældet i medialiseringsteorien, vil der også i denne sammenhæng blive skelnet mellem mediering og medialisering. Mediering henviser til det forhold, at kommunikation foregår igennem et medie - $\mathrm{fx}$ at oplysning om sundhedsfremmende foranstaltninger foregår igennem en trykt pjece, et tv-program eller en hjemmeside på internettet frem for gennem den direkte kontakt mellem borger og eksempelvis læge. Medieringen af en sådan kommunikation kan selvfølgelig ændre på både dens form og indhold, men i sig selv ændrer den ikke nødvendigvis på den lægelige ekspertise eller forestillinger om sundhed som sådan. Øges derimod graden og omfanget af mediering, og bliver medierne den vigtigste kilde til information og kommunikation om sundhed (Strömbeck, 2008, p. 230) og bliver tilmed referencen til, hvad, folk mener, er sundt primært hentet fra medierne, kan man tale om en begyndende medialisering. Da vil såvel kommunikationens indhold og form som sundhedsvæsenet som sådant skulle forholde sig til, at brugere, patienter og personale i stigende grad orienterer sig ud fra og stiller forventninger til både sundhedsvæsenet og deres egen krop og tilværelse på baggrund af en medieformidlet viden. Medialisering handler derfor ikke kun om, at bestemte sociale og kulturelle aktiviteter foregår i medieret form, fx informationssøgning eller lægekonsultation over nettet; Medialisering er udtryk for "den længerevarende proces, hvorigennem institutioner og interaktionsmåder ændres i kultur og samfund som følge af mediernes øgede betydning" (Hjarvard, 2008, p. 30). På sundhedsområdet kunne det eksempelvis betyde, at forholdet mellem læge og patient ville ændre sig på grund af et højere informationsniveau fra patientens side som følge af dennes øgede adgang til information om sundhed på internettet; eller det kunne 
betyde, at borgerne enten undlod at opsøge egen læge og forlod sig på deres medierede viden, eller omvendt at de havde brug for langt flere lægebesøg for at få styr på de mange og til tider modstridende oplysninger om sundhed på internettet - alt sammen med konsekvenser for fx opfattelsen af både anvendeligheden og troværdigheden af den lægevidenskabelige ekspertise og institution som sådan.

Medialiseringsprocesser indebærer med andre ord, at mediernes logik bliver medkonstituerende for sociale og kulturelle aktiviteter. Medierne tænkes så at sige med fra begyndelsen og befinder sig i den forstand ikke i en særlig position 'uden for' den sociale virkelighed, hvorfra de kan påvirke kultur og samfund. Medierne er derimod så integrerede, selvfølgelige og vigtige, "that their formats, content, grammar, and rhythm - the media logic - have become so pervasive that basically, no social actors requiring interaction with the public or influence on public opinion can ignore the media or afford not to adapt to the media logic" (Strömbeck, 2008, p. 238). Medialiseringen viser sig på det mikrosociale niveau ved at gribe strukturerende ind i den menneskelige interaktion, men den viser sig også, som Hjarvard fremhæver, på et makrosocialt niveau ved, at institutioner påvirkes i deres indbyrdes samkvem som følge af mediernes mellemkomst (Hjarvard, 2008). Formidler tv oplysning om sundhed, udgør tv-mediet et interface imellem $\mathrm{fx}$ sundhedsstyrelsen og den enkelte familie, der ser de pågældende tv-programmer. Medierne konstituerer "en falles erfaringsverden, dvs. de bidrager fortløbende med en præsentation og fortolkning af, hvordan verden er indrettet, og i sammenhæng hermed bidrager de til identitetsdannelse og tilhørsforhold til et bestemt kollektiv" (Hjarvard, 2008, p. 47). Ved at formidle og etablere en sådan fortolkningshorisont er medierne en væsentlig aktør i udviklingen af forestillinger om, hvad sundhed er.

Internettet har haft en afgørende indflydelse på både omfang og tilgængelighed af sundhedsinformation, ligesom det har influeret på, hvordan de øvrige medier behandler sundhedsrelaterede stofområder. Aldrig har så mange mennesker haft så let adgang til individuelt at opsøge og få information om sundhed og sygdom (Wright et al., 2008, p. 12). Undersøgelser viser da også, at folk i høj grad benytter sig af internettet til både informationssøgning og interaktiv udveksling af viden og erfaringer (Fox \& Rainie, 2000; Rice \& Katz, 2001). Det betyder, at hvor det hidtil har været sundhedsjournalistikkens opgave at dække og udlægge det sundhedsinformative indhold (Mølster, 2009), er det i dag fx også andre internet-brugeres kommentarer og oplysninger, der danner den forklarende og fortolkende ramme omkring de oplysninger, den enkelte mediebruger søger. Når, på denne måde, "ulike former for partnerskap med publikum fremelskes", udfordres den hidtidige journalistiske ekspertise (Eide, 2009, p. 34). Parallelt med denne udvikling er sundhedsstoffet $i$ aviser og på tv kommet til at fylde mere i livsstilsprægede sektioner og tv-programformater, der til gengæld kan varetage en anden og ny - iscenesættende og fortolkende - rolle i forhold til den information og viden om sundhed, som læsere og seere i højere grad end tidligere, qua deres internetbrug, kan antages at sidde inde med. Mediernes interne arbejdsfordeling har givet et større spillerum for lancering af sundhedsstof på både internettet og i de traditio- 
nelle medier. Ikke mindst har udviklingen givet mulighed for at præge forestillingerne om, hvad sundhed er, i nogle nye retninger, hvor sundhed som livsstilsmarkør er kommet til at spille en stor rolle, og hvor sundhed som emne derved har åbnet sig som et underholdningspotentiale for medieproduktion.

\section{Sundhed og livsstil som mediestof}

I det følgende skal vi se nærmere på de forestillinger, der formidles om sundhed i medierne, først og fremmest i dansk public service-tv. Undersøgelsen vil basere sig på en empirisk, kvalitativ indholdsanalyse af udvalgte programmer om sundhed på DR med henblik på en udredning af det diskursive indhold i forestillinger om sundhed og på en karakteristik af den form for sundhedsekspertise, der cirkulerer i danske tv-programmer om sundhed i perioden 1990-2012. Det empiriske grundlag for analysen afgrænses til to programserier, dels Laegens bord, sendt på DR i en ti-årig periode fra 1997-2006 og serien Ha' det godt!, sendt på DR 1 fra 2007-10, men der vil blive henvist til andre programmer om sundhed på DR og TV2, hvor det forekommer relevant.

Begrundelsen for at drage sammenligninger imellem netop disse to serier er, at $\mathrm{Ha}^{\prime}$ det godt! afløste den hidtil længstkørende serie om sundhed, Løgens bord, i 2007, hvorfor en sammenligning kan give indblik i de forandringer, der fandt sted fra det gamle til det nye program. Ha' det godt! afløste imidlertid ikke blot Lagens bord; Lagens bord fortsatte faktisk i en meget forkortet form som et integreret studieindslag i den nye programserie. Analysen vil lægge vægt på problemstillinger, der knytter sig til programseriernes formål, deres genre, seer-adresseringen samt deres vidensformidlende sigte. Det er hensigten at specificere forholdet mellem programmernes oplysende og underholdende potentialer samt belyse, hvilke former for ekspertise - og dermed også hvilken form for viden om sundhed, tv-programmer på hovedkanalen i prime time tendentielt fremmer.

Der vil blive argumenteret for, at den måde sundhed tematiseres på specielt i den sidste del af periodens sundhedsprogrammer abonnerer på en forståelse af sundhed som sundhedsfremme, som individuelt livsstilsprojekt og som en form for entrepreneurship, der involverer iværksættermentalitet på såvel kroppens som hele den sociale identitets vegne. Endvidere vil der blive argumenteret for, at dette både er et resultat af det politiske systems og myndigheders livsstilsfokuserede sundhedsforståelse, der finder vej til medierne, og et resultat af en medieprofessionel programproduktionsproces, hvor forestillinger om sundhed formes af de nødvendigheder og medie-interne logikker, som er gældende for moderne modtagerorienteret tv-produktion. Der vil blive argumenteret for, at public service kanalerne er gået fra primært at være formidlere af viden om sundhed, der stammer og henter sin legitimitet fra instanser og institutioner uden for tv-institutionen selv, eksempelvis fra lægevidenskab, sundhedsforskning og anden videnskabelig ekspertise, til at de selv i langt højere grad bliver producenter af en viden om sundhed, der skabes inden for tv-institutionens egne rammer og derfor er lavet under professionel hensyntagen til og finder sin 
legitimitet $\mathrm{i}$ kravet om at kunne tiltrække og fastholde flest mulige seere inden for bestemte målgrupper. Og dette krav afføder behovet for at skabe typer af tv-programmer, der effektivt er i stand til at tiltrække publikum. Argumentet, som skal illustreres på et konkret programniveau, ligger i forlængelse af den analyse af den medieinstitutionelle udvikling, som Hjarvard ser som et led i medialiseringen, og som han beskriver som en udvikling fra, at medierne udgør en kulturinstitution, der repræsenterer forskellige institutioner i en almen arena, frem til at være en medieinstitution, styret af en medieprofessionalisme, der primært har servicering af et specifikt, målgruppedifferentieret publikum for øje (Hjarvard, 2008).

Antagelsen for nærværende analyse er, at sundhed i løbet af 2000'erne kommer til at spille en særlig og vigtig rolle i tv-kanalernes programlægningsstrategier. Dette kan ikke mindst ses af det øgede antal af programmer, der tematiserer sundhedsrelaterede emner. I 1990'erne optrådte temaerne sundhed og sygdom i form af det ugentlige magasinprogram Leegens bord på DR (1997-2006) samt Det geelder dit liv (1991) og Dok2eren (1991-93), begge TV2, mens der derimod inden for de seneste fem år sjældent er gået en aften, uden at sundhed på en eller anden måde har været i fokus i et eller flere programmer - det være sig på både public service-kanalerne og på de kommercielle kanaler.

Sundhedsbølgen begyndte for alvor at rulle ind over de danske tv-skærme med docusoap-serien Livet er fedt (TV2) om en gruppe meget overvægtige menneskers kamp mod de overflødige kilo. Den blev i 2001 startskuddet til en række tv-programmer, der på både nye og forskellige måder beskæftigede sig med sundhed, bl.a. Meretes mave (TV2, 2006), Ha' det godt! med indslaget Chris på vœgten (DR 1, 2007-10), Praxis med indslaget Kernesund familie (TV2, 2008-10), By på skrump (DR 1, 2010) Chris på chokoladefabrikken (DR 1, 2011) og Fedt, fup og fleskesteg (DR2, 2011-). Disse programmer blev for de flestes vedkommende sendt gennem flere sæsoner. De benyttede sig af elementer fra flere forskellige genrer $i$ en mere eller mindre dramatisk formidling af programindholdet, og de valgte ofte at sætte fokus på relativt opsigtsvækkende forhold omkring sundhed, eksempelvis ekstrem fedme. I samme ti-årige periode blev public service-programmerne flankeret af reality-programmer om fedme på de kommercielt drevne kanaler, eksempelvis Tab og Vind (The Biggest Loser (TVDanmark, 2005), Min fede familie (TV3, 2009) og Ekstremt fed (TV3, 2011) samt af adskillige programserier om skønhedsoperationer (Extreme Makeover (TVDanmark, 2004; The Swan (TV3, 2004) og om livet på hospitalsgangene (Hospitalet, TV3 2003) - programmer, der ikke direkte beskæftigede sig med emnet sundhed, men som ikke desto mindre samlet set bidrog til at sætte sundhed på dagsordenen.

De mange sundhedstematiserende tv-programmer skyldtes dels eksistensen af flere tvkanaler, hvor et sådant programindhold kunne sendes og ses, dels at man begyndte at betragte sundhed som et programindhold, der kunne integreres i den prime time livsstilsprogramflade, man, inspireret af især de britiske tv-kanaler, strategisk satsede på (Brunsdon et al., 2001). Programmer om livsstil havde altid været til stede på tv's sendeflade, men fra slutningen af 1980'erne var man, som Palmer redegør for, begyndt at udvikle programmer med et bredere livsstilsperspektiv, der tilbød "to change a person's home, appearance and 
indeed sense of self" (Palmer, 2008, p. 1). På de danske tv-kanaler slog livsstilsstrategien for alvor igennem omkring år 2000 (Carlsen \& Frandsen, 2005; Jensen, 2008; Christensen, 2010b), hvor en tilsvarende programintention gik igen i de ovenfor nævnte programmer om sundhed og livsstil.

Programmer i denne livsstilsflade er kendetegnet ved offensivt at krydse genregrænser, og med sådanne genrehybrider optimeres de kontraktmuligheder og 'gevinster', seerne potentielt kan få ved at se programmerne. Feltet er således blevet mere flydende mellem, hvornår et program i denne flade fremstår som fx et kritisk journalistisk program, et livsstilsprogram, et forbrugervejledningsprogram eller et videnskabsformidlende program (Mølster, 2009; Iversen, 2010). De mange genreelementer, der ofte er til stede i ét og samme program, gør det på den ene side mindre klart, hvad programmets dagsorden er, hvordan det adresserer seerne, og hvad formålet med det følgelig er, hvilket i sig selv rummer en fare for, at seerne falder fra. På den anden side kan de forskellige genreelementer i ét og samme program øge chancen for, at mange seere vil føle sig tiltrukket af programmet, da det kan imødekomme relativt forskellige seer-behov; her kan seerne så at sige få lidt af det hele.

Sundhed er blevet et vigtigt programindhold i denne flade. Udover de direkte sundhedstematiserende programmer som fx $\mathrm{Ha}^{\prime}$ det godt! og Praxis udgør sundhed en generel diskursiv ramme, som andre programmer i fladen forholder sig til på mere indirekte facon. I programmer om mad spiller tematiseringen af sundhed ofte en afgørende rolle, om end sundhed kan være mange ting; hvor fx Anne Larsen var optaget af den slanke krop i programmet Max 30\% (DR 1, 2000) og derfor lavede fedtfattig mad for seerne, er brødrene Price optaget af sundhed på en ganske anden måde i programmet Spise med Price (DR 2, 2008, senere DR 1), der henstiller til selve nydelsen af maden - også af smør - som mål for et godt liv. Forestillinger om, hvad en sund tilværelse kunne være, tager sig fx også ganske forskellige ud, afhængigt af om seerne til Bonderøven (DR 2, 2008, senere DR 1) følger Frank i hans idyllisk landlige omgivelser eller kigger på Kernesund familie (TV2, 2008), hvor en hel familie er sat på en kontrolleret, stram diæt for ad den vej at få en sundere tilværelse, eller om seerne er publikum til den eksperimenterende faktaserie By på skrump (DR1), hvor beboere i den jyske by, Ebeltoft, følges i deres fælles bestræbelser på at tabe sig tre tons i løbet af 12 uger. Det er tydeligt, at sundhed generelt i dette livsstilsslot figurerer som en referenceramme, der, med fokus på sundhed som et spørgsmål om livsstil og ønsket om at kunne mestre 'det gode liv', kan forbinde i øvrigt forskelligt programindhold.

\section{Sundhedsoplysning på tv}

I modsætning til aktuelle programmers fokus på sundhed som et bevidst og reflekteret projekt, der involverer en individuel vilje til forandring, var det gennemgående for 1990'ernes programmer, at de beskæftigede sig med sygdom og lidelser. Udover at varetage et alment og lægevidenskabeligt funderet oplysningssigte om sygdomme og bekæmpelsen af dem var programmerne produceret på en sådan måde, at de også relaterede sig til folks egen 
hverdagslige og praktiske viden om sygdomme. I TV2's programserie Det gelder dit liv (1991) beskæftigede man sig fx med stress set ud fra både et lægefagligt og et lægmandssynspunkt. Bl.a. inviteredes såkaldt almindelige mennesker i studiet for at fortælle om deres lidelser: "vi taler med mennesker, der efter lang tids stresspåvirkning er endt i dyb krise" (23.10. 1991), og i et program om overvægt taler journalisten Klaus Schiang-Frank med folk, som har haft vægtproblemer hele deres liv og som fortæller, hvorfor tynde menneskers velmenende råd om at spise mindre ikke er så ligetil: "i programmet møder vi mennesker, hvis mangel på selvtillid har ført dem direkte til den nærmeste bager. Sorger og mindreværd er blevet druknet i madorgier og marcipanbrød. To kvinder fortæller om deres liv med en "bagage" på mere end 120 kilo, omgivelsernes reaktioner og ikke mindst kampen for at slippe af med fedtet" (30.10. 1991). Her signaleres fra afsenderside en interesse for de inviterede gæster, idet de som erfaringseksperter anerkendes for at besidde en viden, som bør komme andre til kendskab via tv. Programmet giver sig ikke af med konkrete handlingsanvisninger, $\mathrm{i}$ forhold til $\mathrm{fx}$ vægttab, men forholder sig udelukkende orienterende og dét på en måde, så seerne får indblik i problemets omfang og personlige omkostninger. Programserien lægger således op til, at seeren skal gives mulighed for at forstå, men ikke fordømme de personlige skæbner, programmet giver adgang til.

Gennemgående for 1990'ernes serier Det gæelder dit liv, Dok2'eren og Læegens bord var, at afsenderne (tv-kanalerne) forvaltede et dobbelt hensyn: dels varetagelsen af oplysning $\mathrm{i}$ forhold til udbredelsen af videnskabelig baseret viden om årsager til sygdomme og deres behandling, dels varetagelsen af oplysning og indsigt i en alment cirkulerende, folkelig og praktisk lægmandsviden om forebyggelse og helbredelse af sygdomme. Den første opgave angik selve formidlingen af eksakt viden om sygdommes årsager, hvorfor de kunne opstå samt hvilke muligheder videnskaben havde for behandling og forebyggelse. Den anden del af formidlingsopgaven var rettet mod at få seerne til at reflektere over den viden, programmet bibragte dem, så de var bedre rustede til at forstå både syge menneskers situation, specifikke sygdomsforløb og, hvordan man kunne lære at leve med en sygdom - alt sammen baseret på lægers viden og almindelige menneskers råd og erfaringer. Under alle omstændigheder var begge vidensformer: 'at vide at' og 'at vide hvordan' (Gustavsson, 2000) repræsenteret i samtlige programmer og blev bragt ind i tv-studiet af lærde eksperter og erfarne folk udefra. Grundlæggende var der tale om afsenderstyret tv, hvor dagsordenen var at gøre seerne klogere på alverdens sygdomme, uanset hvor relevante de måtte være for seerne. Dagsordenen rettede sig mod almenheden som en arena af fælles interesser. Intentionen var ikke primært at underholde seerne med spændende og eksotiske sygdomme, og slet ikke at involvere seerne på en sådan måde i programmerne, at de blev gjort til dommere over dem, der led af diverse sygdomme.

Selv om disse programserier integrerede et folkeligt, erfaringsbaseret lægmandsperspektiv med det videnskabelige perspektiv, var der dog ikke tale om, at man fraveg 'den gamle' forestilling om sundhed som værende lig med fravær af sygdom. Sygdomsaspektet stod, alt andet lige, i forgrunden for sundhedsaspektet, hvilket alene ses af det forhold, at 
de enkelte programmer ganske enkelt brugte størstedelen af sendetiden på sygdom frem for på sundhed. Den officielt anerkendte ekspert, den lægelige ekspertise, hvis viden var forankret i videnskaben, fremstod som programmernes absolutte autoritet. I det følgende vil vi, i lyset af de foregående overvejelser, se nærmere på de formidlingsintentioner, der prægede Lagens bord.

\section{Videnskabelig ekspertise i Lagens bord}

Det første program i serien Løegens bord præsenteres i programoversigten på denne måde: "Lægen Peter Qvortrup Geisling svarer på spørgsmål og tager aktuelle emner op efter forslag fra seerne. Her om kosttilskud, sex efter blodprop i hjertet og lungebetændelse" (30.01. 1997). Her signaleres, at programmet har karakter af en brevkasse, som kendes fra ugebladene, hvor en læge svarer på spørgsmål fra læserne; endvidere at programmet har sagkundskaben på plads, idet det baserer sig på en lægevidenskabelig ekspertise, men også at man bekymrer sig om at gøre programmet relevant for seerne, idet man tager forslag fra seerne op til behandling i programmet. Der er dog, trods denne seer-appel, tale om et afsenderstyret program, der henter sin legitimitet i videnskabens forklaringer om sygdomme og behandling. Seerne opfordres nok til at indsende spørgsmål, men disse tjener først og fremmest til at understrege, at lægen er i stand til at give forklaringer på principielt alt mellem himmel og jord. Denne hierarkiske forståelse af forholdet mellem læge og patient, vidensformidlende tv-kanal og 'videnshungrende' seer er gennemgående helt frem til 2007, hvor programmet nedlægges.

Programseriens vært er lægen Peter Qvortrup Geisling. Han er programmets ankermand og opholder sig først og fremmest bag sit skrivebord/sin disk i studiet, hvorfra han taler direkte til kameraet. Studiet er indrettet som en lægekonsultation med skrivebord, en torso, et skelet samt plancher på væggene med illustrationer af udsnit af det menneskelige legeme. Fra denne position redegør han grundigt og pædagogisk for, $\mathrm{fx}$ hvordan forskellig medicin virker i kroppen, eller hvordan et typisk sygdomsforløb udvikler sig fra de første symptomer til behandling, efterbehandling og genoptræning. Geislings uddannelse som læge understøtter hans autoritet som programvært. Han bruger sin videnskabelige ekspertise i programmet, samtidig med at han konsulterer andre videnskabelige eksperter for deres specialviden om sygdomme og behandling. Således optræder i hvert program indtil flere speciallæger, fx retsodontologer, hudlæger, børnelæger, psykiatere samt mange andre overlæger, praktiserende læger og vagtlæger.

Som magasinprogram består Legens bord af flere indslag i form af fx on location optagelser fra operationsstuer eller plejehjem, der på hver deres måde belyser programmets emner, men der vendes hele tiden tilbage til studiet. Brevkassestrukturen er gennemgående, og sagligt og neutralt besvarer Geisling spørgsmål om stort set alt: 'hvad er en brissel?', 'har enæggede tvillinger samme fingeraftryk?', 'kan hjertet sidde i højre side og leveren i venstre? 'Hvad er forskellen på en hjerneblødning og en blodprop i hjernen?'. Korte indslag 
giver indblik i patienters sygdomsforløb, fx i konsekvenserne af en lille drengs jordnøddeallergi (13.12. 2001) eller i den første patient i Danmark, som har fået fjernet sin ene nyre ved hjælp af kikkertkirurgi. Nyren har han doneret til sin 29-årige søn, og programmet giver et indblik i, hvordan de to store operationer er gået, og hvordan far og søn har det efterfølgende (30.05.2002).

Den lægevidenskabelige ekspertise ses altså også fra patientside. Der bringes positive historier om patienter, som det enten med succes er lykkedes læger at behandle eller som demonstrerer et overskud af livskraft til at forme en god tilværelse på trods af sygdom. Den positive stemning, oftest i form af taknemmelighed og glæde, fremmes endvidere af indslaget 'Ugens buket'. Geisling giver en buket blomster til en person, der inden for det sundhedsfaglige område i Danmark (eller Grønland) har gjort sig fortjent til at modtage den som en særlig anerkendende gestus fra tv-programmets side. Således forbindes videnskabens abstrakte og ofte svært tilgængelige makro-niveau med det sundhedsfaglige personales og patienternes hverdagslige mikro-niveau, præget af pleje, tålmodighed og omsorg.

Programseriens for-forståelse er, at det frem for alt er lægernes og videnskabens opgave og ansvar at tage sig af sygdomme, helbrede dem og tilrettelægge et efterforløb, der giver mulighed for en tilværelse som både rask og sund. Sygdom er i den forstand noget, der ligger uden for det enkelte menneskes kontrol. Kan sygdommen ikke kureres, er det patientens ansvar at acceptere sin sygdom og lære at leve bedst muligt med den. Denne situation imødekommer programserien da også på to måder: dels med det brede vidensformidlende sigte at udbrede et kendskab til samt en forståelse for, hvordan det er at leve med en sygdom, dels ved at inddrage patienter og lægfolk til at berette om deres erfaringer med egne lidelser. Programmet lægger vægt på at understrege vigtigheden af viden, pleje og omsorg samt kontakt i form af et godt socialt netværk af familie og venner. Dette budskab formidles fra lægens bord, men også fra patienter, som har oplevet sygdom på egen krop. Sådanne erfaringer knytter sig til den mere praktiske dimension af programmets formidlingsintention, som vi skal se på i det følgende.

\section{Praktisk erfaring i Lagens bord}

Foruden formidlingen af den lægevidenskabeligt forankrede viden er programseriens anden drivkraft formidlingen af den erfaringsbaserede viden, som har sin rod i praktiske erfaringer, gjort af lægfolk, med at forebygge og holde symptomer på sygdom i ave. I stort set hvert eneste program optræder lægfolk, der fra studiet, fra deres private hjem eller fra deres ophold på $\mathrm{fx}$ hospital eller plejehjem beretter om erfaringer med lidelser, perspektiver for behandling og forventninger til fremtiden. Disse personer fremstår ikke med nogen sagkyndig autoritet, men repræsenterer blot sig selv med masser af syge-erfaring. Indslagene appellerer til seernes følelsesmæssige indlevelse og forståelse, idet de vidner om, hvor smertefuld eller besværlig sygdom kan være, og dermed viser de det menneskelige ansigt bag al den eksakte og videnskabelige snak om sygdom. Dog rummer disse indslag stort set altid et positivt moment $\mathrm{i}$ form af programmets fokus på enten personens store gå- 
på-mod, på den lægelige ekspertises forventninger til nye behandlingsmetoder i fremtiden eller på argumenter om, at det faktisk er muligt at føre en meningsfuld tilværelse på trods af sygdom.

Formidlingen af den brede, praktiske viden rummer dog også mange, ganske harmløse, hverdagslige emner; $f x$ fortælles om faren for skader med plæneklipperen på ben og hænder, eller hvordan man kan blive i bedre humør af at gå en tur hver dag; der orienteres om hugormes bid og hvad man kan gøre, hvis man bliver bidt, eller der gives gamle husmodertips til midler mod solskoldning. Disse indslag, som tidsmæssigt fylder langt mindre i programmet end de mere videnskabeligt baserede, formidles af ganske almindelige mennesker, der har gjort sig deres egne erfaringer med sådanne ting. Videnskabelige eksperter giver dog også ofte deres faglige besyv med i belysningen af de pågældende omstændigheder, eksempelvis ved at forklare, hvorfor giften i slangens bid kan være livsfarlig. De fungerer dermed som dem, der etablerer en videnskabelig kontekst og forståelsesramme omkring de konkrete vidners praktiske erfaring og viden.

De såkaldte konsekvenseksperter levnes dermed ikke den største plads i programmet, og der hersker ikke tvivl om, at den viden, der udefra bliver hentet ind i tv-virksomheden i form af de officielt anerkendte eksperter, i status står over både lægfolk, programvirksomheden og seerne. Men tilstedeværelsen af repræsentanter for folket derude bag tvskærmene i programmet vidner ikke desto mindre om programseriens forsøg på både at etablere en relation til seerne, som bygger på muligheden for genkendelse og identifikation med programindholdet, og på anerkendelsen af den erfaringsbaserede viden, der findes uden for både lægevidenskabens og tv-institutionens rammer.

Programseriens selvforståelse er præget af forestillingen om, at det bringer forskellige former for viden, der stammer forskellige steder fra, sammen i en fælles arena, hvor den formidles til almen gavn. Henvendelsen til seerne foregår i en inkluderende 'vi'-form, eksempelvis: 'Hvorfor har vi to nyrer?', 'Flere og flere af os udvikler fødevareallergi', 'Mere end 1. mio danskere lider af behandlingskrævende hovedpine', ligesom programværten henvender sig venligt og roligt direkte til seeren med et 'du', eksempelvis 'Har du nogensinde tænkt over, hvad en svangerskabsforgiftning egentlig er?' (15.11. 2001) eller 'Har du også nedsat appetit, en følelse af, at du svæver, dine sanser forstærkes, og berøringer føles elektriske, og at du har mindre behov for søvn? Så kan du få svaret lige om lidt her i Løegens bord' (24.11. 2004).

Ved brug af sådanne direkte og inkluderende henvendelsesformer appelleres til seernes engagement i programmerne. Ligeså relevant er, at henvendelsesformen er udtryk for en bestemt afsender-bevidsthed, der adresserer vidensformidlingen til en formodet bred, interesseret og fælles offentlighed. Der kolporteres således ikke i programmet nogen vurdering af den viden, der formidles, endsige vurdering af de mennesker, der optræder som videnskabelige og praktiske eksperter eller syge mennesker. Denne viden samt de medvirkende står ikke til forhandling blandt medvirkende i programmet eller lægges ud som et spørgsmål om smag og behag. De tages for givet, i og med de stammer fra forskningens verden på den ene side og en mangeårig praktisk erfaringsverden på den anden. Viden formidles 
ikke i form af eksperimenter med medvirkende i programmet; viden formidles fra vidende instanser til seere, som formodes gerne at ville modtage denne viden. Formidlingsleddet er fjernsynsprogrammet, som seerne forventes at have en relation til, der frem for noget andet skal være præget af tillid. Denne relation forpligter på begge sider af tv-skærmen: programmet skal kunne skabe troværdighed omkring det formidlede indhold, og seerne skal kunne stole på indholdet og evt. kunne anvende denne viden i relation til deres eget og andres liv.

\section{$H a^{\prime}$ det godt! - sundhed som livsstil}

Lagens bord ophørte i 2006 og blev overtaget af en ny og anderledes programserie $\mathrm{Ha}^{\prime}$ det godt!. Selv om Lagens bord indgik som et ganske kort indslag, 'Aftenkonsultationen', i det nye program, endog med sin egen, særskilte vært, nemlig Peter Qvortrup Geisling, blev overgangen de to programserier imellem dog markant. Udover dette velkendte indslag bestod $\mathrm{Ha}^{\prime}$ det godt! af en række andre indslag, hvor et hovedtema dog fyldte mere af sendetiden end andre - korte reportager med karakter af make-over føljeton, tests med deltagere, konkurrencer for seerne, korte klip med ekspertudsagn, instruktion i fx træning, samtaler mellem værter og deltagere og møder mellem forskellige mennesker i løbet af programmet. I det flg. skal vi se nærmere på, hvordan det brede vidensformidlende sigte i $\mathrm{Ha}^{\prime}$ det godt! forsvandt til fordel for et fokus på sundhed set i et underholdende livsstilsperspektiv, hvor formidlingsintentionen først og fremmest blev forankret $i$ at ville skabe fascinerende tv-oplevelser.

På DR's hjemmeside for tv-programmet $\mathrm{Ha}^{\prime}$ det godt! blev det præsenteret som "Inspirerende tv". Her stod bl.a. følgende:

\footnotetext{
I Ha' det godt! sættes der i stedet fokus på de hundredtusindvis af danskere, der bærer diagnosen 'rask', men som sagtens kan leve sundere og føle sig bedre tilpas alligevel: Livsstilsrelaterede sygdomme er danskernes nye fælles lidelse. Det søde liv er simpelt hen blevet for sødt. Men vi vil prøve at motivere seerne til at være bedre mod sig selv og deres krop - og de vil finde ud af, at det faktisk slet ikke er så svært at vende skuden (DR, 2007).
}

I denne introduktion leveres kodeordene til at forstå, hvilket program $\mathrm{Ha}^{\prime}$ det godt! er. Det er et program, der vil motivere 'raske' seere til at leve sundere og føle sig bedre tilpas. Disse såkaldt raske danskere har tilsyneladende deres egen dårlige livsstil som fjende. Den betegnes senere i introduktionen som 'ukrudt' og, mener man, giver sig udtryk i 'dårlige vaner' (DR, 2007). Intentionen er at motivere folk til at leve et sundere liv, hvilket skal ske på flg. måde:

For at bevise at det sunde liv er inden for rækkevidde for alle, afprøves der forskellige metoder til at få et sundere liv. Alle områder af kroppens fysiske og psykiske områder kommer $\mathrm{i}$ fokus ved at tage fat på forskellige wellness-kure, diæter, meditationstekniker, træningsprogrammer og kombinationer af det hele (DR, 2007). 
Programmet skal således ikke handle om sygdom, selv om afsættet er nationens livsstilsrelaterede sygdomme. Sundhedsfremme og wellness har forrang for sygdomsaspektet, og der fokuseres på individuelle og konkrete handlingsanvisninger som middel til at få et sundere liv, hvilket dog afgrænses til et fokus på kroppen. Sundhed handler her om at 'afprøve forskellige metoder'.

Programmets vært er Marianne Florman, tidligere professionel håndboldspiller, kendt fra medierne som en gæv, jysk pige, der går op i sport og ved, hvilken ihærdighed der skal lægges for dagen, vil man nå sine satte mål. Desuden medvirker coachen og livsstilseksperten Chris MacDonald i den del af programmet, Chris på vcegten, der drejer sig om såkaldte testpiloter, dvs. såkaldt almindelige mennesker, der har meldt sig til programmet og som udfordres i forskellige tests og eksperimenter med henblik på vægttab. Endelig optræder, som sagt, Geisling som vært i indslaget 'Aftenkonsultationen'.

At programmet har tre værter, indikerer i sig selv, at sundhedsekspertise er et anliggende, som forskellige personer ud over den lægevidenskabelige ekspert kan hævdes at være i besiddelse af. Bortset fra Geisling, der, ligesom i det oprindelige Lagens bord, er placeret i sin 'konsultation', hvorfra han stadig giver forklaringer på diverse sygdomsfænomener, befinder Florman og MacDonald sig ikke på noget tidspunkt i et fast studie. Det betyder dog ikke, at Geisling får rollen som ankermand. Tværtimod fremstår hans studiedel som et lidt langsommeligt afbræk i et ellers høj-dynamisk program, hvor de to andre værter konstant er på farten og i færd med fysiske udfoldelser af forskellig slags. De optræder som aktører på forskellige locations, hvor de dels introducerer diverse tests og instruerer deltagere i den rette adfærd, dels selv indgår som testpersoner i diverse forsøg. Ved inddragelsen af både programmets vært og almindelige mennesker i forsøg og eksperimenter understreges, at sundhed er et spørgsmål, der for det første kræver villighed til at afprøve noget nyt og for det andet, at sundhed angår enhver, uanset hvor sund og rask man selv mener, man er. Risikovillighed med henblik på individuel forbedring bliver således en dyd og en måde at vise seerne på, at alle og enhver kan beslutte sig for at forandre deres livsstil. I modsætning til Geislings afbalanceret venlige og hyggelige attitude signalerer de to værter friskhed, målrettethed, energi og dynamisk handlekraft. Med deres energiske rolle påtager de sig opgaven at få deltagerne til, ikke blot at medvirke i programmet, men at virke som aktører for det.

I den forudgående serie, Læegens bord, blev der jævnligt refereret til diverse sundhedskampagner, fx Hjerteforeningens kampagner om motion og rygning, og seerne blev orienteret om det fornuftige i at dyrke motion og holde op med at ryge. I Ha' det godt! er man naturligvis også for motion og imod rygning, men dette formidles ikke som en generel oplysning til videre overvejelse hos seerne. I $\mathrm{Ha}^{\prime}$ det godt! tiltager programmet sig derimod autoritativt retten til både at facilitere den enkelte deltager i forhold til at træffe et sundere valg og retten til at fordømme samme, hvis valget ikke træffes. Valget om et sundere liv fremstilles nemlig som et krav, deltagerne bør acceptere (de har jo også meldt sig som testpersoner). Valget formidles som et tilbud, der dog hurtigt får en moralsk forpligtende og kontraktlignende karakter: de bør eksempelvis som i Chris på vagten tabe sig meget 
og hurtigt i løbet af de uger, programserien forløber - og tilbuddet forvandler sig til et påbud. Den sundhedsforståelse, der bringes i spil, er derfor først og fremmest et produkt af tv-programmets interne logik, hvor deltagerne for at blive anerkendt som sunde, skal gøre, som vært og coach påbyder, hvorved programmets målsætning om at være et attraktivt tv-program, der tilbyder effektive løsninger, samtidig indfries.

Indslaget Chris på vaegten har fokus på deltagernes store og hårdt kæmpende kroppe i fitnesscenterets maskiner, med nærbilleder af kropsdele, der knokler, og hvor sveden driver. I indslaget indgår også scener fra eksperternes coaching af deltagerne. Her fremstår det som en selvfølgelighed, at deltagerne lader sig presse ud over deres både fysiske og psykiske grænser for at tabe sig; fx går en test ud på, at deltagerne skal tabe 1 kilo fedt på 12 timer. Udover dette indslag er hele programseriens ide baseret på, at værten Florman i hvert program udsætter sig for grænseoverskridende oplevelser, såsom at blive sin skræk for slanger kvit ved at bære en slange, eller tage med en jæger på jagt og skyde en buk, hvorefter hun bryder sammen. Efter disse og lignende ekstreme oplevelser bekender Florman hver gang over for seerne, at der er noget positivt i at lade sig presse til det yderste, hvilket dermed fremstår som programmets naturlige budskab.

Dramaturgisk er serien $\mathrm{Ha}^{\prime}$ det godt! forskellig fra Legens bord, der var karakteriseret ved et roligt fortælletempo med lange kameraindstillinger og omhyggelige udredninger om krop og sygdom fra lægens side. I Ha' det godt! er der dramaturgisk tilstræbt et højt aktivitetsniveau. Dels klippes frem og tilbage mellem de forskellige locations og personer flere gange i løbet af programmet, hvilket giver seeren en oplevelse af dramatik og stor dynamik; dels er værter og deltagere konstant i gang med nye aktiviteter på vej ind eller hen til nye opgaver, hvilket sammen med det høje tempo understøtter programmets intention om at fungere inspirerende og motiverende med henblik på handling og forandring: det handler om at komme igang.

Et andet dramatiserende element i serien er tests, forsøg og eksperimenter, der kan forøge seernes oplevelse af at være underholdt, idet de giver programmet et spændingsmoment. Spilleregler, tidsfrister, faste mål og milepæle opstilles konstant for såvel deltagere som værten Florman, og udgør målestokken for, hvorvidt de har succes eller ej. Programmets drivkraft er bundet til denne spænding om udfaldet, snarere end til muligheden for som seer at tilegne sig ny viden om sundhed. Seerne præsenteres for personer, der, foranlediget af en vis form for tvang, insisterer på at fremme individuel sundhed ved at overskride egne grænser. Sundhed bliver et spørgsmål om, hvorvidt den enkelte er i stand til at fremvise et tilstrækkeligt strategisk forhold til sin egen krop og gøre den til genstand for en privat iværksættermentalitet. Verden uden for tv-programmets iscenesatte virkelighed, hvor den enkelte deltagers sundhed afhænger af en lang række strukturelle betingelser som arbejde, økonomi, sociale forpligtelser mv., eksisterer ikke, så længe programmet kører, hvorfor kroppen kan gøres eneansvarlig for den enkelte deltagers sundhedstilstand. 


\section{Know how-eksperter}

Den vidensdimension, $\mathrm{Ha}^{\prime}$ det godt!-serien rummer, er tæt knyttet til dette dynamiske aspekt. Viden knytter sig til demonstration af viljen til hurtig forandring og handling samt til resultaterne af de eksperimenter og tests, vært og deltagere medvirker i - eller rettere, det er selve aktiviteten, at de pågældende personer involverer sig i eksperimentelle handlinger, der formidles en viden om. Det er selve forandrings-paratheden, der står i fokus. Seerne får konkret syn for sagen ved både at få indblik i de skeptiske overvejelser inden forsøget, dernæst at blive vidne til det hårde slid eller den grænseoverskridende oplevelse og ved at få adgang til de følelsesmæssige reaktioner, personerne giver udtryk for undervejs og umiddelbart efter at have deltaget i forsøget. Programmet er optaget af at skildre konkrete personer og de aktiviteter, de giver sig i kast med, takket være tv-mediets motiverende indsats samt at fremvise, at forsøgene omgående har effekt, der kan aflæses dels på vægten, dels på deltagernes følelsesmæssige tilkendegivelser.

Da programserien ikke opererer med sygdom, etableres ikke et traditionelt læge-patientforhold på samme måde som i Lagens bord. I Ha' det godt! er det ikke videnskabelige eksperter, der skal formidle deres fagligt 'tunge' viden, som står i front. Til gengæld optræder et ganske andet og stort antal eksperter i form af coaches, livsstilseksperter, fitnesseksperter, kostkyndige, terapeuter, der alle sammen inden for deres felt skal støtte deltagere i programmet i motivationen og viljen til forandring. Disse know how-eksperters rolle er ikke primært at formidle deres viden til tv-seerne, men derimod at sætte et eksperiment op, som kan demonstrere, hvordan en forandringsvilje kan omsættes til konkret, individuel handling her og nu (Christensen, 2010), og dermed få programmets ide til at fremstå som vellykket.

Disse eksperters opgave er ikke at beskrive og forklare, men at inspirere, overbevise og handlingsanvise ud fra devisen hjælp til selv-hjælp. Således illustrerer programserien helt på linje med de livsstilsprogrammer, som omgiver den, at livsstilsmedier adresserer et Do It Yourself Self (Lewis, 2007). På den ene side er dén forestilling gennemgående, at enhver er ekspert i sit eget liv, hvilket bl.a. udgør Chris McDonalds legitimitet i programmet; på den anden side legitimeres diverse eksperters tilstedeværelse i programmet ved, at de skal motivere den enkelte til at ændre adfærd samt finde og opdyrke det 'egentlige selv' hos personen. Dette 'egentlige selv' fremstår imidlertid ikke som forbundet med former for identitet som fx socialt tilhørsforhold, etnicitet eller køn. Det 'selv', der appelleres til, er defineret ganske minimalt ved at være ren og skær krop, modellérbar og indstillet på forandring. Når programmet således adresserer et slet og ret forandringsparat individ i form af den rene, instrumentelle krop og psyke, der kan og bør bearbejdes og kontrolleres, er vejen åbnet for, at principielt enhver type ekspert, der passer ind i tv-formatet, kan tiltage sig autoritet til at handlingsanvise.

\section{Sund eller usund?}

Bortset fra indslaget 'Aftenkonsultationen', hvor Geisling kortfattet og ud fra et forebyggelsesperspektiv redegør for diverse sygdomslignende tilstande og kropslige reaktioner såsom 
hikke, forkølelse, prop i øret og depression, er det karakteristisk for programmet, at sygdom sjældent nævnes. Det forhold, at sygdom ofte er ensbetydende med manglende kræfter og et mere stillestående liv, finder ikke plads inden for programmets selvforståelse. Det nærmeste programmet kommer på italesættelse af sygdom, er i korte interview-indslag med testpiloternes familiemedlemmer eller kolleger, der ytrer sig om angsten for, at den pågældende testperson kunne blive syg, hvis han eller hun ikke taber sig. Disse nært relaterede personer fungerer som understøttende vidner i forhold til programmets overordnede målsætning: at vise, at det står galt til med rigtig mange mennesker, uden at de selv er klar over det eller gør noget ved det. Desuden fungerer de som belæg for, at usund livsstil har konsekvenser for mange andre end 'den usunde' selv, hvorved der på den ene side skabes indlevelse i disse personers ængstelse, mens bekymringen på den anden side også fungerer som en moralsk retfærdiggørelse af en fordømmende holdning overfor den pågældende testperson.

Indenfor programmets rammer er det i princippet ikke muligt blot at vere sund som en tilstand, man kan befinde sig i, eller føle sig sund, for sundhed betyder i denne type program at blive sund og holde 'dårlige vaner' fra døren og aktivt forvalte sin sundhed. Sundhed er et individuelt anliggende, der er fikseret i kroppen og dyrkelsen af den og involverer et performativt aspekt. Sådan som tv-programmet er skruet sammen, afkræves deltagerne nemlig en fremvisning af viljen til at forandre og forbedre deres krop. Det indebærer en tilbagevendende refleksion over, hvorvidt man overhovedet er sund nok, og en opfattelse af kroppen og psyken som et instrument og bearbejdeligt materiale herfor - et materiale, som skal kunne kontrolleres. Sat på spidsen er den sunde krop, som den fremstilles i en programserie som $\mathrm{Ha}^{\prime}$ det godt!, én af mediet ansvarliggjort krop, en kontrolleret krop i kraft af den individuelle styrkelse, empowerment, som mediet foranlediger, og den er, ikke mindst, god underholdning.

\section{Tv som sundhedsguide}

Set $\mathrm{i}$ et public service-perspektiv, hvor DR har sundhedsoplysning for øje, er der langt mellem Læegens bord og Ha' det godt!! Perspektivet har forskudt sig fra et fokus på sygdom som et faktisk vilkår, kroppen mere eller mindre tilfældigt kan blive ramt af på grund af omstændigheder og vilkår, som den enkelte ikke selv har det fulde ansvar for - til at sygdom, eller rettere: ikke-sundhed fremstilles som et vilkår af abstrakt karakter, hvor kroppen betragtes som en trussel og potentiel risiko, som det er op til den enkelte selv at tage ansvaret for gennem personligt udfordrende og grænseoverskridende handlinger og ved en ændret adfærd og livsstil.

Af den grund adresseres seerne anderledes i Ha' det godt! end i Lagens bord. For det første adresseres de som individuelle aktører, der på linje med enhver entreprenør bør tage sundhedsprojektet i egen hånd. Sundhed forstås som et spørgsmål om individuel attitude og livsstil, defineret ud fra et valg om, hvorvidt man ønsker at være fit eller ej, og hvorvidt man vil tage ansvar for egen sundhed. I den forstand kører tv et vist parallelløb med de 
forestillinger om sundhedsfremme, der gør sig gældende på det sundhedspolitiske niveau. For det andet adresseres seerne på en sådan måde, at de, på linje med deltagerne i programmet, forventes at stille sig velvillige over for at modtage den service, som tv-programmet yder i form af eksperters råd, der skal motivere beslutninger om livsstilsændring. Det er imidlertid tv-programmet selv, der udstikker de krav, der skal opfyldes, hvorfor deltagerne i kraft af deres deltagelse primært tilfredsstiller programmets logik og dets professionelle gennemførelse, mens de først i anden omgang muligvis, eller måske slet ikke, tilfredsstiller egne sundhedsfordringer.

På den måde kan man tale om en medialiseringsproces, hvor både sundhedsforestillinger og ekspertise tilpasses tv-mediets professionelle logik, der først og fremmest handler om at producere seervenlige programmer, der harmonerer med den øvrige, underholdende sendeflade. Målet for dens slags programmer er ikke primært at fungere som formidlende platform for viden fra en anden institution uden for tv-institutionens rammer. Den viden, der i disse år kolporteres i tv's sundhedsprogrammer, benytter sig af, hvad man kunne kalde, mediets selvopfundne know-how-eksperter, der netop er karakteriserede ved, at de går ind på mediets egen logik om effektivt underholdende vidensformidling. Af denne viden kræves, at den er operationaliserbar her og nu, og at såvel deltagere i programmet som seere hjemme i stuerne motiveres og inspireres til forandring - hvilket $\mathrm{fx}$ kan ske ved hhv. at slide for et vægttab for åben skærm, hhv. at gøre sig til moralsk dommer over dem, der i mindre grad formår at udfylde programmets intention. Med know-how-eksperterne som hovedaktører bliver det mediet selv, der overhovedet kommer til at sætte rammerne for de forestillinger om sundhed og ekspertise, der udvikles og distribueres, nemlig at opnåelsen af sundhed sker i form af en pakkeløsning bestående af fix og færdige løsninger på ofte endog store sundhedsproblemer.

På denne baggrund kan man sige, at seerne i dag stifter bekendtskab med sundhedsproblematikken på $\mathrm{t} v \mathrm{i}$ en både bredere og snævrere forstand end tidligere. Bredere i den forstand, at sundhedsbegrebet som sagt knyttes til livsstil og dermed ikke kun er defineret som fravær af sygdom, men rummer 'bløde' aspekter som wellness, livskvalitet og 'det gode liv'. Sundhed er ikke knyttet snævert til modstillingen mellem den raske og den syge krop, men omfatter principielt hele tilværelsen og det hele menneske og figurerer derfor diskursivt i flere typer af programmer om mad, bolig, træning, udseende og familieliv.

Omvendt kan man også tale om en snævrere sundhedsproblematik i den forstand, at programmer om sundhed primært varetager en underholdende funktion med de konsekvenser, det har for valg og fravalg af perspektiver på sundhed. Eksempelvis har overvægt og fedme haft en altoverskyggende bevågenhed i de sidste ti års tv-programmer, mens $\mathrm{fx}$ perspektiver på sundhedsmæssige konsekvenser af fattigdom og miljøforurening har været stort set fraværende. Konkurrencer, tests og personlige dramaer med emotionelt 'blod, sved og tårer' har derimod gennem en årrække markeret sig som nogle af de mest centrale komponenter i dansk public service-tv's sundhedsformidlende indsats. 
I denne optik bliver sundhed et spørgsmål om et personligt game show, hvor viljen til både personlig og hurtig forandring i efterlevelsen af fastsatte spilleregler og moralske normer bliver afgørende. Forestillinger om, hvad sundhed er eller kunne være, bliver afpasset de krav, som tv-mediet stiller for dramatisk vellykket underholdning, der kan skaffe høje seertal. Den medmenneskelige forståelse for, hvad sygdom er og kan medføre, samt den appel til tidskrævende pleje, omsorg og sociale netværk, som lå i programintentionerne for Læegens bord, skal man således kigge langt efter i moderne tv-programmer om sundhed, der snarere dyrker den hurtige entreprenørløsning.

\section{Referencer}

Bonner, F., McKay, S. \& Goldie, K. (1998). Caring for the Family: Fifty years of health in the Australian women's weekly. Journal of Australian Studies 59, 154-164.

Brinch, S. \& Iversen, G. (2010). Popular vitenskap. Kristiansand: Høyskoleforlaget.

Brunsdon, C. et al. (2001). Factual entertainment on British television. European Journal of Cultural Studies 4(1), 29-62.

Carlsen, J. \& Frandsen, K. (2005). Nytte- og livsstilsprogrammer på dansk tv. Arbejdspapir 133, Center for Kulturforskning, Århus: Aarhus Universitet.

Christensen, C.L. (2010). Livsstilsprogrammer. Hverdag og underholdning. In H. Bruun \& K. Frandsen (Eds.), Underholdende TV (pp. 121-147). Århus: Aarhus Universitetsforlag.

Christensen, C.L. (2010b). Lifestyle as factual entertainment. In J. Gripsrud (Ed.) Relocating Television. Television in the Digital Context (pp. 125-138). London: Routledge.

Corner, J. (1999). Critical Ideas in Television Studies. Oxford: Oxford University Press.

Danmarks Radio (2007). Ha' det godt. Om programmet. Konsulteret oktober 2012, http://www.dr.dk/DR1/ hadetgodt/Om_programmet/20070810135123.htm.

Danmarks Statistik (2012). Levevilkår. Tema: Måling affattigdom. København: Danmarks Statistik.

Eide, M. \& Hernes, G. (1987). Død og pine! Om massemedia og helsepolitik. Oslo: FAFO.

Eide, M. (2009). Journalistiske nyorienteringer. En introduktion. In M. Eide (Ed.) Journalistiske nyorienteringer (pp. 9-40). Oslo: Scandinavian Academic Press.

Featherstone, M. \& Hepworth, M. (1991). Body, Social Process and Cultural Theory. London: Sage.

Fox, S. \& Rainie, L. (2000). The online health care revolution: How the web helps Americans take better care of themselves. Washington D.C.: Pew Charitable Trusts.

Gustavsson, B. (2000). Vidensfilosofi. Århus: Klim.

Hjarvard, S. (2004). From bricks to bytes: The mediatization of a global toy industry. In I. Bondebjerg \& P. Golding (Eds.), European Culture and the Media (pp. 43-65). Bristol, Portland, Or: Intellect.

Hjarvard, S. (2008). En verden af medier. Medialisering af politik, sprog, religion og leg. Frederiksberg: Samfundslitteratur.

Iversen, G. (2010). Programmet som gir deg et bedre liv. In S. Brinch \& G. Iversen, Popular vitenskap (pp. 126-152). Kristiansand: Høyskoleforlaget.

Jensen, P.M. (2008). The international extent and elasticity of lifestyle television. In MedieKultur 45, 37-50.

Juel, K., Sørensen J., \& Brønnum-Hansen H. (2006). Risikofaktorer og folkesundhed i Danmark. København: Statens Institut for Folkesundhed (SIF). 
Kline, K.N. (2006). A decade of research on health content in the media: The focus on health challenges and sociocultural context and attendant informational and ideological problems. Journal of Health Communication 11, 43-59.

Lewis, T. (2008). Smart living: lifestyle media and popular expertise. New York: Peter Lang.

Lewis, T. (2007). 'He Needs to Face his Fears With these Five Queers!': Queer Eye for the Straight Guy, Makeover TV, and the Lifestyle Expert. Television and New Media 8(4), 285-311.

Mølster, R. (2009). Liv, helse og journalistikk - på TV. In M. Eide (Ed.) Journalistiske nyorienteringer (pp. 195220). Oslo: Scandinavian Academic Press.

O'Brien, M. (1995). Health and lifestyle: A critical mess? Notes on the dedifferentiation of health. In R. Burton, S. Nettleton, \& R. Burrows (Eds.), The sociology of health promotion: Critical analyses of consumption, lifestyle, and risk (pp. 191-205). London: Routledge.

Palmer, G. (Ed.) (2008). Exposing Lifestyle Television. The Big Reveal, (pp. 1-13). Aldershot: Ashgate.

Puijk, R. (Ed.) (2008). Fjernsyn i digitale omgivelser. Kristiansand: IJ-forlaget.

Qvarsell, R. (1989). Människan och hennes hälsa: Om hälsobegreppets och hälsoupplysningens idéhistoria. In S. Philipson, N. Uddenberg et al. (Eds.), Hälsa som livsmening (pp. 94-117). Natur och kultur, Stockholm: Gotab.

Regeringen (1989). Regeringens forebyggelsesprogram. København: Sundhedsministeriet.

Regeringen (2002). Sund hele livet - de nationale mål og strategier for folkesundheden 2002-10. København: Indenrigs- og Sundhedsministeriet.

Rice, R. \& Katz, J. (2001). The Internet and Health Communication: Experiences and Expectations. California: Sage.

Schulz, W. (2004). Reconstructing mediatization as an analytical concept. European Journal of Communication, 19(1), 87-101.

Strömbeck, J. (2008). Four phases of mediatization: An analysis of the mediatization of politics. The International Journal of Press/Politics, 13, 228-246.

Tjønneland, E. (2008). Kultur og livsstilsjournalistikken på 1700-tallet. In K.A. Knapskog \& L.O. Larsen (Eds.), Kulturjournalistikk. Pressen og den kulturelle offentligheten. Oslo: Spartacus Forlag - Scandinavian Academic Press.

Vallgårda, S. (2003). Folkesundhed som politik. Danmark og Sverige fra 1930 til i dag, Århus: Aarhus Universitetsforlag.

Warsh, C. K. (Ed.) (2011). Gender, Health, and Popular Culture. A Historical Perspective. Ontario: Wilfrid Laurier University Press.

WHO (1946). Preamble to the Constitution of the World Health Organization as adopted by the International Health Conference, 19-22 June, New York.

Wright, K. B. et al. (2008). Health Communication in the 21st Century. London: Blackwell.

Christa Lykke Christensen

Lektor, Ph.d.

Film og Medievidenskab

Institut for Medier, Erkendelse og Formidling

Københavns Universitet, Danmark 